\title{
Erratum to: "Interactions of Three Dominant Ant Species, Lasius emarginatus (Ol.), Formica rufa L., and Lasius fuliginosus (Latr.) (Hymenoptera, Formicidae) among Themselves and with Subordinate Species in Broadleaf Forests. Communication 1" [Entomological Review 96 (6), 747-767 (2016)]
}

\author{
S. V. Stukalyuk \\ Institute for Evolutionary Ecology, National Academy of Sciences of Ukraine, Kiev, 03143 Ukraine \\ e-mail: asmoondey@gmail.com
}

Received November 13, 2017

DOI: $10.1134 / \mathrm{S} 0013873817070168$

Page 760

"According to the data of Peral and co-authors (2016), the nest density of the subordinate ant species (especially the aggressive $L$. platythorax) was significantly lower in the territories of the narrow-headed ant $F$. exsecta Nylander, 1846 than in those of the blood-red ant F. sanguinea Latreille, 1798" should be as follows: "According to the data of Trigos Peral and co-authors (2016), the nest density of the subordinate ant species (especially the aggressive L. platythorax) was significantly lower in the territories of the narrow-headed ant F. exsecta Nylander, 1846 than in those of the blood-red ant F. sanguinea Latreille, 1798."

Page 766

Reference no. 28 should be as follows:

28. Trigos Peral, G., Markó, B., Babik, H., Tăuşan, I., Maák, I., Pálfi, Z., Ślipiński, P., Czekes, Z., and Czechowski, W., "Differential Impact of Two Dominant Formica Ant Species (Hymenoptera, Formicidae) on Subordinates in Temperate Europe," Journal of Hymenoptera Research 50, 97-116 (2016). 